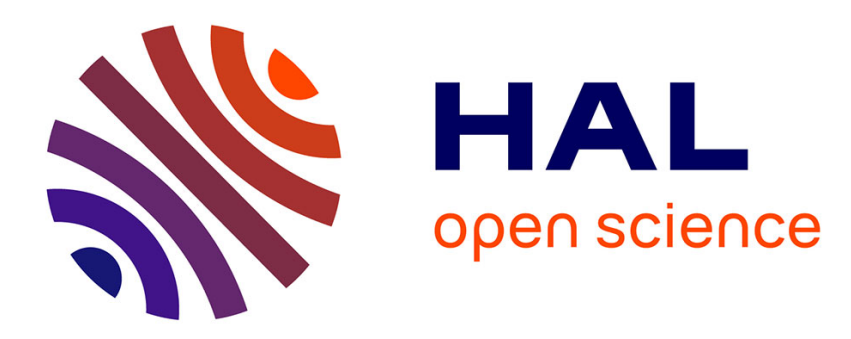

\title{
Legal Knowledge and Local Practices under the Early cAbbāsids
}

\author{
Mathieu Tillier
}

\section{To cite this version:}

Mathieu Tillier. Legal Knowledge and Local Practices under the Early ${ }^{\mathrm{c}}$ Abbāsids. Philip Wood. History and Identity in the Eastern Mediterranean, 500-1000, Oxford University Press, pp.187-204, 2013. halshs-00827952

\section{HAL Id: halshs-00827952 \\ https://shs.hal.science/halshs-00827952}

Submitted on 30 May 2013

HAL is a multi-disciplinary open access archive for the deposit and dissemination of scientific research documents, whether they are published or not. The documents may come from teaching and research institutions in France or abroad, or from public or private research centers.
L'archive ouverte pluridisciplinaire HAL, est destinée au dépôt et à la diffusion de documents scientifiques de niveau recherche, publiés ou non, émanant des établissements d'enseignement et de recherche français ou étrangers, des laboratoires publics ou privés. 


\title{
Legal Knowledge and Local Practices under the Early
}

\author{
'Abbāsids \\ Mathieu Tillier \\ Institut français du Proche-Orient
}

Islamic jurisprudence (fiqh) developed as a normative pluralism resulting in the formation and diffusion of several schools of law in the principal centres of Islam. The schools of law (madhhab pl. madhāhib,) —in particular the Hanafī, Mālikī, Shāfi 's̄, and Hanbalī, which are the main Sunn̄̄ schools that developed in the Islamic empirereached their classical form only in the fourth/tenth century, with several features such as a common doctrine, institutionalized teaching, and authoritative leaders for each individual school. ${ }^{-}$This was the result of a long process that began in Iraq under the early 'Abbāsids, between the late second/eighth and the early third/ninth century, when the eponyms of these schools lived and taught. The first 'Abbāsid caliphs played a considerable role in the promotion of several of these schools of law, as Nurit Tsafrir has shown in respect to the spread of the Hanafī madhhab. ${ }^{2}$

According to Joseph Schacht, the development of the classical schools of law resulted in the transformation from 'regional' into 'personal' schools of law. The ancient Iraqi school, which united around a common 'living tradition', evolved in the third/ninth century into a new school associated with the authority of Abū Hanīfa and his most important students, Abū Yūsuf and al-Shaybān̄̄. $\underline{3}$ This shift corresponded to a globalization of legal thought, in which law was no longer anchored within one specific province of the caliphate. This theory has been recently challenged by Nimrod Hurvitz and Wael Hallaq, who refute the reality of any 'regional' school of law. They doubt that a common doctrine existed before the establishment of the classical schools of law (which they prefer to call 'doctrinal schools' rather than 'personal'), and they believe that no early legal doctrine had any potency beyond the small circle of students around a particular master. ${ }^{4}$

The latter theory, which is accurate from a purely legal point of view, does not take into account the subjective feelings of the people. I believe that the historian should pay more attention to how people who had a common way of life and a common way of thinking represented themselves when it came to legal matters. I will look specifically at what happened in certain cities in the early Islamic empire. Was there any sort of legal identity ${ }^{\frac{5}{}}$ evident between one place and another? To answer this question, we have to leave the above-mentioned theories and focus on the connection between the local urban elites and the government. I will seek to investigate the role that the urban elite in several 
Iraqi cities - and, to a lesser extent, in Fustat - played in selecting and appointing the $q \bar{a} d \bar{l} \overline{\mathrm{s}}$ during the early 'Abbāsid period (132-218/750-833). I shall draw principally on the two sources for the history of the judiciary at that time: the Akhbār al-qud̄ât of Wakī' (d. 306/918), a biographical dictionary of qāọ̄s (mostly in Iraq), and the Akhbār qud̄āt Mișr of al-Kindī (d. 350/961), which focuses on Egyptian judges. Before discussing the essential issues, it is necessary to mention briefly certain legal problems in the middle of the second/eighth century, and to examine who the qā appointed.

\section{Unity and Diversity: Legal Issues under the Late Umayyads and Early} 'Abbāsids

The legal situation in Iraq in the middle of the second/eighth century appears clearly in one of the rare contemporary Arabic sources, the Risāla fi al-șahāaba by the chancellery secretary Ibn al-Muqaffa' (d. c. 140/757). ${ }^{6}$ In this famous epistle, the author warns the caliph al-Manșūr (r. 136-58/754-75) about the legal diversity that is dividing the Islamic realm, including the province of Iraq itself. He cites as examples the cities of Hīra and Kufa, which, although situated near each other, applied different rules for similar crimes or offences. In fact, contradictory judgments could even be given in different parts of the same city. ${ }^{7}$

The contradictions emphasized by Ibn al-Muqaffā' are a reflection of a wider phenomenon on which Schacht based his theory of the ancient schools of law. In the middle of the second/eighth century, three principal regional schools of law divided the Islamic Middle East: there was an Iraqi school, based on the jurists of Kufa and Basra; a Hijāzī school, based on the jurists of Medina and Mecca; and a Syrian school. $\stackrel{8}{\text { These }}$ three schools represented divergent legal movements and proposed different solutions for the same problem. Ibn al-Muqaffa's Risāla fì al-ṣahāba also shows that there were divisions within these regional schools. As Hallaq and Hurvitz suggested, it is probable that each circle of jurists had its own doctrines (as, for example, in Kufa, which was divided into several distinct schools of thought associated with particular parts of the city); nevertheless, it is also probable that, at a certain level, the people were aware of some kind of local 'super-schools', each one corresponding to a specific city. It is enough, for the time being, to emphasize the considerable legal diversity at that time, whether in Iraq or in Arabia (Medinese legal thought probably differed slightly from the Meccan).$\underline{9}$

After the revolution that toppled the Umayyads in 132/750, the 'Abbāsid caliphs had to deal with this legal diversity. To overthrow the previous dynasty, the 'Abbāsids had relied on a broad political movement of Shī'i inspiration that supported the family of the Prophet. Once in power, the elected member of the family (al-riḍ $\bar{a} \min \bar{a} l$ 
Muhammad) was supposed to restore justice and apply divine law. ${ }^{10}$ It is probable that some sort of legal reform was expected from the new dynasty and that Ibn al-Muqaffā's epistle reflected these popular expectations. The multiplicity of rules for just one crime (even major ones such as murder or illegal sexual intercourse) suggested that some of them, at least, did not comply with divine law. The unification of the law could therefore be seen as a major way to restore justice. Ibn al-Muqaffa' proposed to al-Manșūr a remedy for this legal diversity: the codification of Islamic law. The caliph would promulgate a unique legal code and would impose it on all the qāạts of the empire. This code would be updated by each subsequent caliph. ${ }^{11}$ According to later Muslim sources, al-Manșūr asked the Medinese jurist Mālik ibn Anas (the eponym of the Mālikī school, d. 179/795) to write such a code, but Mālik refused. $\stackrel{12}{ }$ Benjamin Jokisch argues that codification was eventually enforced under Hārūn al-Rashīd (r. 170-193/786-809). $\frac{13}{\text { I }}$ will come back to this later. All in all, it seems that a legal unification was difficult to enforce, because the elaboration of law was already regarded, in the main cities of the empire, as the prerogative of private scholars.

\section{The Judiciary in the Middle of the Second/Eighth Century}

\subsection{A local institution}

During the late Umayyad and the early 'Abbāsid periods, a single qạd $\bar{l}$ was appointed in every large city, whose duties were both legal and administrative. From the early Umayyad period, if not earlier, his main task was to dispense justice between litigants who had filed complaints before him, most often in the city's great mosque. 14 From the early 'Abbāsids onwards, the $q \bar{a} d \bar{l}$ became a major administrator of the city and was sometimes expected to intervene in private business, when people could no longer manage their own affairs. In Egypt, as Sobhi Bouderbala has shown, the tribal administrators known as 'ariffs managed the property of orphans under the Umayyads, but this authority was transferred to the $q \bar{a} d \bar{l}$ under al-Manșūr. ${ }^{15}$ At the same time, the $q \bar{a} \underline{d} \bar{\imath}$ of Basra began to manage the pious foundations (waqfs), the orphans' properties, and the inheritance of people dying without an heir (hashriyyat). $\stackrel{16}{ }$ These administrative tasks were subsequently upheld by legal theory. .17

The origins of the rules applied by the qā relied on the Qur'an and on normative practices (sunan) of exemplary men (including caliphs), and they contributed importantly to the drawing up of legal norms by the use of their personal opinion or $r a^{\prime} y . \underline{18}$ There was no definitive or binding written legal corpus yet. As far as we can trace them, the first 'fixed' compendia of jurisprudence emerged in the late second/eighth and the early third/ninth century, with the formation of the protoHanafī and proto-Mālikī madhhabs. ${ }^{19}$ Despite their adherence to legal trends, qā still choose the most appropriate legal solution to a specific issue, $\frac{20}{2}$ and it was not until 
the late third/ninth or the early fourth/tenth century, with the formation of formal schools of law, that qā $\bar{l} \overline{\mathrm{s}} \mathrm{s}$ had to comply with the legal rules promoted by their own madhhab. The $q \bar{a} d \bar{l} \bar{s}$ did not enjoy total freedom, because their rulings could be controlled by the government, which could easily dismiss them from their position. ${ }^{21}$ Nevertheless, they could, in many cases, apply their personal understanding of legal and social order, and they played a leading part in the shaping of an 'Islamic' society. Two qā middle of the second/eighth century exemplify this ambiguous role: the famous jurist Ibn Abī Laylā (d. in office, in 148/765), who served as a judge in Kufa at the end of the Umayyad period and under the first 'Abbāsid caliphs, ${ }^{22}$ is well known for his contribution to the formulation of judiciary procedures based on his opinions and experience. ${ }^{23}$ In Basra, the $q \bar{a} d \bar{l} \overline{~ ' U b a y d ~ A l l a ̄ h ~ i b n ~ a l-H a s a n ~ a l-~ A n b a r i ̄ ~(d . ~ 168 / 785) ~ c o n t r i b u t e d ~ t o ~ t h e ~}$ definition of the fiscal status of the regions near his city and refused to act on the legal and fiscal instructions of the caliph al-Mahdī (r. 158-69/775-85). ${ }^{\underline{4}}$

Judgeship was a key institution for the people of a city. The resolution of many problems depended on the $q \bar{a} \underline{d} \bar{l}$ - on his legal opinions and on his judgements. From the middle of the second/eighth century onwards, state administrators and scholars began to work out theories about the 'good' $q \bar{a} d \underline{l}$-his qualities and his knowledge. Later reflections, within the classical schools of law, unsurprisingly attached importance to the judge's legal knowledge. In the second/eighth century, however, thinkers such as the chancellery secretary (kātib) 'Abd al-Hamīd ibn Yahyā (d. 132/750) or the qā Allāh ibn al-Hasan al- 'Anbarī focused mainly on the social knowledge and experience of the judge: even though a legal background was required, such knowledge could be provided by counsellors whose advice the judge was supposed to seek. A lack of social knowledge, however, could not be counterbalanced: the $q \bar{a} \underline{d} \bar{\imath}$ had to understand the urban society in which he was appointed, and figure out the complex familial and tribal relationships, such as, for example, in sharing out an inheritance between the legal beneficiaries. $\underline{25}$

Despite many common features, the inhabitants of every large city developed their own original characteristics following the Islamic conquests. Although Basra and Kufa were founded at the same time and in the same region, different tribes had settled there, and they had developed their own urban models. The Yamanī tribes of Kufa, for example, maintained their ancient tradition of gathering in cemeteries, which resulted in urban structures unknown in Basra. ${ }^{26}$ Each city had its own needs, and at the end of the Umayyad period, the judiciary was still seen as a local institution. This was possible largely because of the decentralized organization of the state.

Until the reign of al-Manșūr, the second 'Abbāsid caliph, the qā appointed by the governors of the cities or provinces. The caliph rarely intervened in their appointments. The $q \bar{a} d \bar{l}$ appeared as a kind of 'legal secretary' of the governor, who was considered to be the actual holder of the judgeship, and delegated his judicial powers to the $q \bar{a} d \bar{l} .^{27}$ The turnover of the governors was high, however, and most of them were sent 


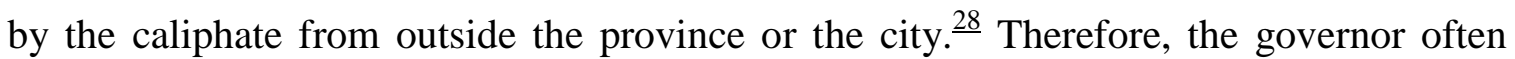
relied on the advice of the local elite when appointing a $q \bar{a} d \underline{\imath}$. If a $q \bar{a} d \bar{l}$ died or was dismissed, he consulted the notables to learn whom they wanted as a replacement. This system was still apparent in the early 'Abbāsid period, under al-Saffāh and at the beginning of the reign of al-Manșūr. ${ }^{29}$

Not only were the notables involved in the selection of the $q \bar{a} d \bar{l}$, but the $q \bar{a} d \bar{l}$ was also generally chosen from amongst the local elite itself. In Umayyad Iraq, the judges were local scholars supported by notables. In Fustat, all qādīs belonged to the leading Yamanī clans of the city, such as Haḍramawț, Khawlān, and Sakūn. $\frac{30}{}$ The judiciary was regarded as a local institution employing local inhabitants, and this local framework may well have contributed to a local or regional development of Islamic law.

\section{2. 'Abbāsid centralization}

Almost two decades after the 'Abbāsid revolution, the caliph initiated one of the most significant reforms of the dynasty, namely, the centralization of the state and judiciary. Al-Manșūr and his successors decided that virtually all the judges in the empire should be appointed by the central government (the caliph, sometimes his chief judge, and later his vizier). $\frac{31}{}$ The first appointment by al-Manșūr took place in Basra in $140 / 757, \frac{32}{2}$ and twenty years later all the $q \bar{a} d \underline{\bar{l}} \mathrm{~s}$ of the central provinces of the empire (including Fustat, Damascus and Medina) were appointed by the caliphate. ${ }^{33}$ The $q \bar{a} \underline{q} \bar{\imath}$ was now dispensing justice in the name of the caliph. If we remember that the 'Abbāsid revolution intended to restore justice on earth, after the allegedly illegitimate Umayyad dynasty, and that the first 'Abbāsid caliphs claimed to be rightly guided rulers and deputies of God, $\underline{34}$ we realize that this reform was symbolically significant. Moreover, it helped the caliphs increase their power by restricting that of the provincial governors. The latter were no longer responsible for carrying out justice and were therefore significantly weakened. They had lost the privileged relationship they had had with local scholars and had to deal with qā $\bar{d} \bar{\imath}$ s who were now their equals - both now being appointed directly by the caliph — and whose administrative responsibilities in each city were increasing.

The centralization of the judiciary can also be interpreted as an attempt to unify legal practices and to reduce the heterogeneity denounced by Ibn al-Muqaffa'. If the caliphs could hardly codify Islamic law, which was already in the hands of private

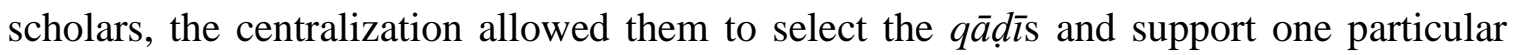
legal trend or another. As Nurit Tsafrir has shown, $\underline{35}$ this was probably one of the main reasons for the centralization, and 'Abbāsid legal policy is evident in the appointments of the $q \bar{a} d \bar{l} \overline{\mathrm{s}}$ in the capital, al-Hāshimiyya and later Baghdad.

During the 25 years that followed the 'Abbāsid revolution, the caliphs favoured mainly the Medinese school of law: they chose their $q \bar{a} d \bar{l} \mathrm{~s}$ from amongst the scholars of Medina and persuaded them to come to Iraq. $\frac{36}{}$ Why did they choose to rely on this legal 
trend? The sources are unfortunately silent about their motivation, but the following hypothesis can be made. The first 'Abbāsid caliphs (al-Saffāḥ and al-Manșūr) came from Syria, while their armies came from Khurāsān (an eastern province of Iran). When the new dynasty settled in Iraq, the political elite was not accustomed to Iraqi legal thought (founded on the practices and the traditions of the Companions and Successors who had

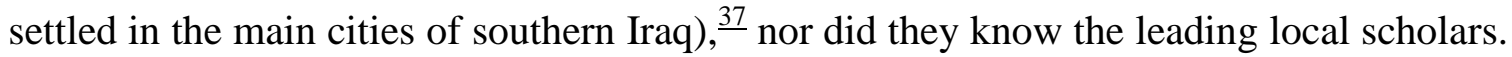
According to Ibn al-Muqaffa', Iraqi scholars had suffered from a poor reputation under the Umayyads, and the new power may have been hesitant to integrate them fully into their administration. ${ }^{38}$ Moreover, many Iraqi scholars (especially the traditionists) were pro-'Alid and regarded the 'Abbāsids as usurpers. The first 'Abbāsid caliphs may therefore have been reluctant to employ them. $\frac{39}{}$ They could not rely on Syrian jurists such as al-Awzā $\overline{1}^{-40}$ without giving the impression that they were following Umayyad practices, thereby losing the support of the Khurāsān̄ army. They therefore had to find a legal tradition that would seem to comply with divine will. For many people, Medina probably appeared as the preserve of the sunna (tradition) inherited directly from the Prophet. The scholars of this city saw themselves as the heirs of the true practice ('amal) of the Prophet, unbroken in Medina since the time he preached there. ${ }^{41}$ The caliphs may have hoped that these Medinese scholars would confer a wider legitimacy on the new dynasty, which would appear to be working for the restoration of the sunna of the Prophet.

From the reign of al-Mahdī (the third 'Abbāsid caliph, r. 158-69/775-85) onwards, the $q \bar{a} d \bar{l}$ s of Baghdad were drawn mainly from amongst Iraqi scholars, especially from

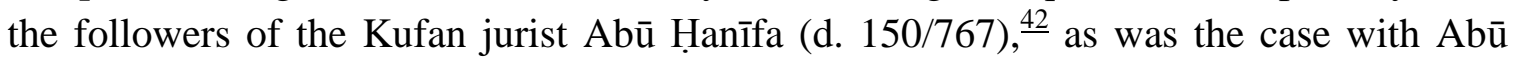
Yūsuf (d. 182/798), the first $q \bar{a} d \bar{l} \bar{l}$ to be given the title of 'chief $q \bar{a} d \bar{l}$ ' ( $q \bar{a} d \bar{l}$ al-quḍat). According to Nurit Tsafrir, the main reason for this change of legal policy was theological. Like Abū Hanīfa, most of his students were apparently Murji 'ìs who believed that the status of a sinner was postponed until the Day of Resurrection. Therefore, they refused to question the ruler and were considered to be particularly loyal to the 'Abbāsid dynasty. $\frac{43}{}$

This interpretation does not, however, take into consideration the fact that early Murji'ism was a more revolutionary movement than it became in the third/ninth century,, 44 and that Abū Hanīfa's attitude toward the 'Abbāsids was ambiguous. $\stackrel{45}{\text { Other }}$ reasons - probably legal-might explain the 'Abbāsids' support of proto-Hanafīs, and this issue needs further research that is beyond the scope of this chapter. Be that as it may, the 'Abbāsids quickly extended their policy beyond Baghdad by the means of centralization and appointed members of Abū Hanīfa's circle as qā $\underline{\bar{l}} \overline{\mathrm{s}} \mathrm{s}$ in other cities of Iraq and the Middle East, thus promoting what would eventually become the Hanafî school of law. $\underline{46}$ 
Mathieu Tillier, « Legal Knowledge and Local Practices under the Early 'Abbāsids », in Philip Wood (ed.), History and Identity in the Eastern Mediterranean (New York: Oxford University Press), 2013, p. 187-204.

\section{The Resistance of Local Elites to 'Abbāsid Centralization}

\subsection{An 'Abbāsid absolutism?}

In spite of the centralization ordered by the 'Abbāsid caliphs, the judiciary did not immediately lose its local characteristics, nor did urban elites forget their interest in the appointment of $q \bar{a} d \bar{l} \mathrm{~s}$. This can be seen clearly in the city of Basra, where a new judge was appointed in 156/773. Wakī relates the following story:

'Ubayd Allāh ibn al-Ḥasan al-Mu' addib reported from al-Numayrī, from 'Abd al-Wāḥid ibn Ghiyāth, from Jannāb al-Khashkhāsh, from Sallām ibn Abī Khayra:

After Sawwār's death,,$\underline{\text { }}$ we talked about him at 'Ubayd Allāh ibn al-Ḥasan's, who implored God in his favour and praised him. We asked 'Ubayd Allāh:

'Who do you think would be suitable for the judgeship after him?'

'That is obvious', he replied. 'Abū Bakr ibn al-Faḍl al-'Atakī'.

Then we visited Abū Bakr and talked about Sawwār. He implored God in his favour and we asked him:

'Who do you think would be suitable for the judgeship after him?'

'Is there any doubt about that?' he replied. 'It can only be one man: 'Ubayd Allāh ibn al-Hasan'.

Sallām ibn Abī Khayra said:

We were surprised by their common agreement on the matter.

Even though this narrative is told to highlight the importance of these two scholars ('Ubayd Allāh ibn al-Hasan al- 'Anbarī and Abū Bakr ibn al-Fạ̣l al-'Atakī) and their modesty, it may also show how discussions took place in the selection of new qādīs. In this story, the scholars do not suggest the candidate most likely to be selected by the caliph, but rather express their opinion on who deserved to become a qāạ .

How did they dare speak out about this matter, when judges were now appointed by the central authority according to a wide political programme that promoted the standardization of legal practice? Some scholars believe that this programme was the result of an autocratic system, in which the arbitrary power of the caliph was absolute. $\stackrel{49}{ }$ But centralization did not mean despotism, as Nurit Tsafrir has clearly shown. ${ }^{50}$ The legitimacy of the 'Abbāsid dynasty was not well enough established to allow the caliphs to impose their legal and judicial policy by force. They could easily experiment with a new legal policy in Baghdad because it was a new city, built almost ex nihilo and without

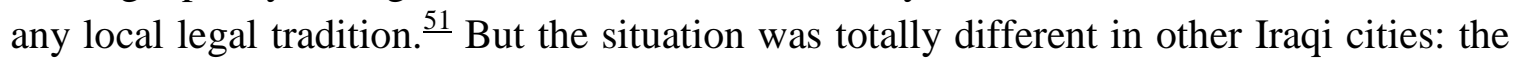
so-called 'Abbāsid 'revolution' was regarded by many people as a usurpation of power, either at the expense of the Umayyads (according to the majority of Syrians) ${ }^{\underline{52}}$ or of the 'Alid family. The crystallization of the Shī' 1 opposition around 'Alid leaders such as the Hasanid Ibrāhīm ibn 'Abd Allāh (d. 145/763), who revolted in Basra under al-Manșūr, $\underline{53}$ jeopardized the caliphate in Iraq. The 'Abbāsids could not afford to impose any legal 
reform against the wishes of the local elites, lest opposition to their dynasty be strengthened.

\subsection{Dealing with local issues}

The centralization of the judiciary was a long process, and the method of selecting the $q \bar{a} d \underline{\imath} \bar{s}$ did not change immediately. The first 'Abbāsid caliphs still consulted local people before appointing a judge and summoned to Baghdad delegations (wafd, pl. wufüd) made up of notables. The sources give several examples of delegations coming from Basra to meet the caliphs al-Mahdī and al-Rashīd (r. 170-93/786-809). These delegations usually consisted of five or six notables and scholars from the city, representing different legal and theological trends. $\underline{54}$ The caliph received them and asked whom they wanted as qāali. In 167/783-4, the governor of Basra, Muhammad ibn Sulaymān, chose a delegation of six local notables and sent them to the caliph al-Mahdī. The governor wanted them to insist that the caliph dismiss Khālid ibn Talīq, a qāa $\bar{l}$ who was apparently hated by many Basrans. Although the delegation was used as a tool by the governor to obtain the dismissal of Khālid ibn Țalīq, each member felt free to propose his own candidate to replace the dismissed judge, and it seems that the local elite could make themselves heard. Moreover, according to the list reported by Waki' delegation were representatives of rival groups in Basra, such as partisans of $r a^{\prime} y$, partisans of hadīth, proto-Hanafīs, members of the Basran legal trend, and $\mathrm{Mu}$ 'tazilīs. $\underline{55}$ Although the delegation consisted of only six men, they represented a large section of the Basran elite. Such consultations of the local elite did not mean that the 'Abbāsids renounced their programme of legal unification in favour of the proto-Hanafî trend, but it did mean that the enforcement of this programme was limited by local wishes $\underline{56}$.

The consultation of the provincial elite had perhaps a symbolic meaning: the caliph had to show that he was not a tyrant. As a deputy of God, however, he could claim to have a better understanding of legal issues and to have the right to appoint whomever he wanted as $q \bar{a} d \bar{l}$. The issue was therefore not merely symbolic. The caliph was ready to take the delegations' opinion into consideration, which means that the local wishes were seen as important. The city's notables insisted particularly on having a 'local' qāậ. Émile Tyan has interpreted this request as a matter of 'national pride' $\underline{57}$ Evidence shows that the reality was more complex. It seems that an ability to understand local practices was a key criterion in the selection of $q \bar{a} d \underline{\imath} \bar{s}$, a criterion that could be verified only by people who were familiar with local practices.

Two examples from Iraq can be cited to illustrate this hypothesis. Yahyā ibn Sa '̄id al-Anșārī (d. 143/760?), a Hijāzī jurist who had been a judge in Medina under the Umayyad caliph al-Walīd II (r. 125-6/743-4) $)^{\frac{58}{2}}$, was appointed $q \bar{a} \underline{\bar{l}} \bar{\imath}$ of al-Hāshimiyya by al-Saffāḥ or al-Manșūr. $\frac{59}{}$ Just before leaving Medina for Iraq, Yahyā ibn Sa īd prided himself on 'knowing everything' in the presence of Sulaymān ibn Bilāl al-Qurashī (d. c. 172/788-9), a Medinese scholar who had been in charge of land tax in his city. ${ }^{60}$ Later, 
however, Sulaymān ibn Bilāl received a letter in which Yahyā ibn Sa '̄id complained that he could not understand some of the litigations brought before him in court and that, in such cases, he did not know which judgement to pass. He requested the secret assistance of another Medinese jurist, Rabī'a al-Ra'y (d. 136/753). ${ }^{61}$ Although Wakī' is silent about the nature of these problematic cases, we can suppose that Yahyā ibn Sa'īd's Medinese legal training was inapplicable to many aspects of Iraqi society.

The second example is from about 145/762, when the Egyptian jurist and $q \bar{a} d \bar{l}$ Ghawth ibn Sulaymān (d. 168/785) went to Iraq and was asked by the caliph al-Manșūr to arbitrate on a matrimonial conflict between him and his wife, Umm Mūsā. Subsequently, the caliph proposed to appoint him qā $d \bar{l}$ of Kufa. Ghawth ibn Sulaymān protested that he was not from that city (balad) and that he knew nothing about its inhabitants. According to al-Kindī, Ghawth was appointed $q \bar{a} d \underline{\imath}$ of Kufa, but after a while

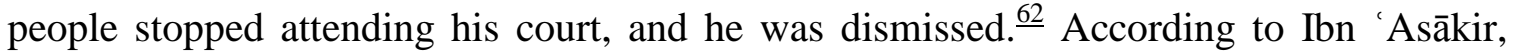
however, al-Manșūr accepted his excuse of not being familiar with the city and never appointed him to Kufa; this is probably closer to the truth, because Ghawth ibn Sulaymān does not appear in Wakī' 's list of Kufan judges..$^{63}$ The first 'Abbāsid caliphs supported, to a certain extent, the ancient Egyptian school of law, and several leading Egyptian scholars were attracted to Baghdad. $\frac{64}{}$ However, even though al-Mansūr appealed to an Egyptian jurist to arbitrate his personal litigations, he could hardly appoint such a 'stranger' as a $q \bar{a} d \underline{l}$ to a major Iraqi city. If he actually did, as al-Kindī maintains, the appointment failed, because the Kufans would not accept a judge who could not understand the particularities of their society.

\subsection{A question of legal doctrine: central authority versus local interests}

In several instances, the delegations sent to the caliph opposed the promotion of proto-Hanafī $q \bar{a} d \bar{l} \bar{s}$, not only because they were 'strangers' unable to understand local cases, but also because of their legal doctrine. The notables were attached to their local traditions and were not ready to accept a $q \bar{a} \underline{d} \bar{\imath}$ belonging to a different legal trend. Some feared that such a judge would seriously disrupt the urban order and harm the people's material interests. When the caliph al-Mahdī consulted the delegation of Basrans in 167/783-4, one of them suggested the appointment of a local scholar, Muhammad ibn

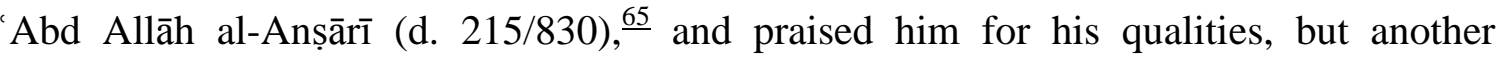
member of the delegation contradicted him, saying:

'He spoke truly, and indeed he has all these qualities. However, this advice is not wise, because this man follows Abū Ḥanīfa and inclines towards his opinions $\left(r a^{\prime} y u-h u\right)$. Yet, we have in our city rules $(a h k \bar{a} m)$ that Abū Hanīfa considers invalid, but which are the only ones suitable for us. If he judged our litigations on the ground of rules other than our own, our rules would become void, and our goods would be lost' - he seemed to be alluding to the pious foundations. $\frac{66}{6}$ 
It was eventually another scholar, faithful to the Basran legal tradition, who was appointed by the caliph. This story shows that at the end of the eighth century CE, the representatives of the Basran people regarded the doctrine of the Kufan Abū Hanifa as a foreign one. ${ }^{67}$ Despite divergences between local circles of jurists, they were all more or less united around a local common practice, especially regarding the administration of pious foundations. Abū Hanīfa contested the validity of permanent pious foundations established for relatives (waqf ahli)), which could be used to evade Islamic law on inheritance. According to him, a waqf was valid only if the founder established it as from the moment of his death; $; \underline{68}$ moreover, only the descendants of the founder who had already been procreated by the time the founder died were entitled to a share in the revenues of the foundation. When these descendants died, their shares had to be transferred to indigent people, so that no more than two or three generations could benefit from the revenue of a pious foundation. ${ }^{69}$ If such family foundations were a traditional practice in Basra, the prosperity and wealth of many Basrans would have been threatened by a proto-Hanafī $q \bar{a} d \underline{\bar{l}} \mathbf{l}^{\underline{70}}$

The elite of Fustat also rejected a proto-Hanafī $q \bar{a} d \bar{l} \bar{\imath}$ coming from Iraq, Ismā '̄ll ibn Alīsa' (164-7/781-4). He wanted to apply the same rule in Egypt and was accused of trying to abrogate the pious foundations. ${ }^{71}$ In addition, the people of Fustat reproached him for tolerating the insult $y \bar{a} m a$ 'būn, ya $\bar{l} \bar{u} t \bar{l}$ (an accusation of passive homosexuality), which he did not consider punishable by the prescribed sanction (hadd) for false accusation of fornication (qadhf). ${ }^{72}$ Once more, he followed the teaching of Abu Hanifa, who did not regard such an insult as a crime as long as it was vague enough, whereas Mālik ibn Anas assimilated it to qadhf and ordered the culprit to be punished harshly. ${ }^{73}$ Like their principal jurist, al-Layth ibn Sa'd (d. 175/791), the inhabitants of Fustat were strongly opposed to homosexual behaviour and thus to false accusations of homosexual behaviour. ${ }^{74}$ The Hanafī doctrine might have been seen to jeopardize public morality in Fustat.

In Egypt, as in the Iraqi amșār (military settlements), the Hanafĩ doctrine promoted by the central government was not easily accepted. Until the reign of al-Rashìd, at the end of the second/eighth century, the Basran people prevented the caliph from appointing any $q \bar{a} d \bar{l}$ from amongst the followers of Abu Hanifa and demanded that scholars be recruited from within the local legal tradition. $\frac{75}{}$ Even in Kufa, where the students of Abu Hanifa were only one of the prominent circles of jurists, the government could not appoint scholars who can be safely identified as proto-Hanafīs until the reign of al-Amīn (r. 193-8/809-13). The judiciary remained in the hands of the followers of Ibn Abī Laylā, Abū Hanīfa's main rival. $\underline{\text { 6 }}$

The wishes of notables were thus the principal obstacle to the 'Abbāsid policy. Several times, the caliph appointed a $q \bar{a} d \bar{l}$ in Basra against the wishes of the inhabitants, but usually such a $q \bar{a} d \underline{\imath}$ stayed in office for no more than one or two years, whereas $q \bar{a} d \bar{l} \mathrm{~s}$ appointed in accordance with the wishes of the people stayed in office for an average of 
five or six years. ${ }^{77}$ The most striking example is that of 'Abd al-Raḥmān ibn Muhammad al-Makhzūmī, a Hanafī $q \bar{a} d \bar{l}$ appointed in Basra in 172/788-9 against the wishes of the people: he was dismissed just four months later. ${ }^{78}$ Wakī ${ }^{`}$ explains that he could not resolve the litigations brought before him and that he hesitated before issuing a judgment diverging from local legal traditions:

Al-Aḥwaṣ ibn al-Mufaḍḍal ibn Ghassān reported from Ḥaf̣̣ ibn 'Uthmān:

We saw a woman who had submitted a case before 'Abd al-Rahmān ibn Muhammad al-Makhzūmī, the qāại of Basra. When she became impatient to hear his judgment, he stood before her and said: 'I have difficulties with your case, even though I know what is right and not wrong according to my [own doctrine]. Be patient. If you want me to talk to the governor, so that he convenes the jurists of Basra for you, I can do that. And if you want, I shall write to the Commander of the Faithful and ask the jurists of the Muslims who sit next to him' $\underline{79}$

The $q \bar{a} q \bar{l}$ could not issue a judgement in conformity with local practices, perhaps because he did not understand these practices - or because he simply would not depart from his beliefs. On the other hand, he could not impose his own doctrine and bring upon himself the litigants' wrath. He therefore left the decision to the assembly of local scholars or to the jurists of the caliph's court (presumably Hanafīs like himself).

\subsection{Towards a marginalisation of ancient provincial elites}

The centralization of the judiciary had long-term consequences for the provincial elite. Despite the role that the first 'Abbāsid caliphs still accorded to local notables in the selection of $q \bar{a} \underline{d} \bar{l}$ s, the reform initiated by al-Manșūr can also be interpreted as an attempt to undermine their power. This attempt was eventually successful, as shown by the history of Egyptian qādi $\bar{\imath}$ s.

The first $q \bar{a} d \underline{l}$ appointed by al-Manșūr in Fustat, 'Abd Allāh ibn Lahī'a (d. 174/790), was still a representative of the old class of Egyptian notables (wujūh) who controlled the key institutions in Fustat, such as the position of șăhib al-shurța (chief of the police).$\stackrel{80}{ }$ A few years later, however, the caliph al-Mahdī appointed, for the first time in the history of Egypt, a qa $\bar{a} d \bar{l}$ who did not belong to the local elite, but came from Iraq (Ismā'îl ibn Alīsa', who was also a follower of Abū Hanīfa). ${ }^{81}$ He was so unpopular that the caliph had no choice but to dismiss him and replace him with an Egyptian scholar (Ghawth ibn Sulaymān, and then al-Mufaḍụal ibn Faḍāla). In 170/786, the caliph al-Hādī (r. 169-70/785-6) appointed a new 'outsider' in Fustat, the Medinese 'Abd al-Malik ibn Muhammad al-Hazmī, followed a few years later by the Iraqi Muhammad ibn Masrūq. At first, the caliphs sent $q \bar{a} \underline{d} \bar{l}$ s from Yamanì tribes, because they probably believed that they

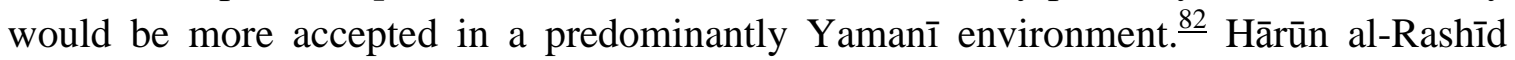
soon abandoned this precaution and appointed Qaysī qāḍ̂̄s such as al- Umarī and alBakrī. 
The centralization of the Egyptian judiciary has been interpreted as part of a wider programme of legal unification under the (proto-)Hanafī trend. $\underline{83}$ Not all the qā from Iraq were Hanafīs, however. Al-Hazmī belonged to the Medinese/proto-Mālikī school, as did al- 'Umarī and, later, Muhammad ibn 'Abd Allāh al-Zuhrī (217-26/83240). $\frac{84}{}$ In Egypt, at least, the centralization of the judiciary meant first and foremost a reinforcement of caliphal authority. The caliphs tried, as far as possible, to send qāadis belonging to the madhhab that they personally supported, which was not always the Hanafī school. Al-Rashīd probably sent al-'Umarī to Fustat when he turned to the Mālikīs, after the death of Abū Yūsuf, and appointed the Medinese Abū al-Bakhtarī as chief $q \bar{a} \underline{\underline{l}} \overline{\underline{8}} \underline{85}$

The fourth fitna (the war between al-Amīn and al-Ma'mūn and its aftermath) temporarily defeated the efforts of the caliphate to enhance its authority. Between 197/813 and 211/826, Egypt became virtually autonomous. $\frac{86}{\text { The }}$ wujūh were able to regain control of Fustat, and $q \bar{a} \underline{d} \bar{l}$ s were appointed from within the old established families who had long monopolized the institution, but this reversal of affairs was short lived. In 211/826, the governor 'Abd Allāh ibn Ṭāhir re-established 'Abbāsid authority in Egypt, and the traditional Yamanī wujūh disappeared from the political scene forever. $\frac{87}{\mathrm{~A}}$ new ruling elite came to power. Most of the $q \bar{a} d \bar{l} \bar{i}$ s were now outsiders and belonged to Qaysī tribes. Even though Muhammad ibn Abī 1-Layth (226-35/841-50) had lived in Fustat for twenty years when he was appointed $q \bar{a} d \bar{l} \bar{l}, \underline{88}$ he was a Hanafī from a Qaysī tribe and, as the principal participant of the mihnna ${ }^{1}$ in Fustat in the $840 \mathrm{~s}, \stackrel{89}{ }$ he representedmore than anyone - the coercive power of the central government. ${ }^{90}$

In Iraq, the influence of the local elites was still evident at the beginning of the third/ninth century. The number of Hanafī qā following decades. This does not mean that a central power was imposed on a reluctant people. The proto-Hanafî school had supposedly gained ground in these two cities, and the caliphate could more easily appoint $q \bar{a} \underline{d} \bar{l} \mathrm{~s}$ belonging to this school of law. ${ }^{91}$ Nevertheless, the influence of the local elite soon declined. As was the case in Egypt, the provincial elite of Kufa and Basra no longer played a part in the selection of their $q \bar{a} d \bar{\imath} \mathrm{s}$, and we do not hear about any delegation after the return of al-Ma'mūn (r. 198-218/81333 ) to Baghdad in 204/819. Individual scholars were consulted before the appointment of a $q \bar{a} d \bar{l}$ under al-Mutawakkil (r. 232-47/847-61), but they were no longer representatives of the local peoples. $\stackrel{92}{ }$ Between the fourth fitna and the second half of the third/ninth century, most of the qā $\bar{d} \bar{\imath}$ s in Kufa were still drawn from local scholars, but they no longer belonged to the dominant Yamanī clans (such as Nakha') from within which judges had usually been selected in the second/eighth century. .93 The spread of doctrinal schools of law caused a standardization of knowledge that was soon reinforced by a 'traditionalization' of law in which a 'universal' Muhammad replaced the local

\footnotetext{
${ }^{1}$ The mihna is the 'inquisition' that al-Ma'mūn organized to impose the dogma of the creation of the Qur'an.
} 
Companions as the source of legal practice. This doctrinal standardisation no longer left a place for local legal practices as they had existed. Thereafter, local practices could be recognized only insofar as they were assimilated into the main madhhabs. $\stackrel{94}{ }$

\section{Conclusion}

During the second half of the second/eighth century, appointments to the judiciary in Iraq and Egypt were the subject of strenuous competition between the local elite and the central government. Negotiations for the selection of appropriate candidates, which can be seen as evidence of the close collaboration between the local elite and the central government, do not conceal the issues at stake. The caliphate tried to increase its authority in the main provincial cities and reduce legal heterogeneity in the empire. The local learned elite resisted this policy in order to preserve its traditional power and local interests.

At first, the 'Abbāsids' lack of legitimacy required some concessions, and the provincial elite succeeded in keeping some of its special prerogatives in the selection of $q \bar{a} d \bar{l} \overline{\mathrm{s}}$ until the end of the second/eighth century. The first 'Abbāsid caliphs had to take into account the interests and particularities of the local situation: they could not afford to muzzle local wishes without renouncing their claim to restore justice. Benjamin Jokisch argues that Hanafî law was imposed by the central power on the Islamic empire by the means of judges. ${ }^{95}$ This theory is weakened by the fact that the central power and the local elite were at that time in a permanent negotiation. In the third/ninth century, however, the reinforcement of caliphal authority (particularly during the mihna) and the evolution of political structures resulted in a definitive marginalisation of the local elite.

In the long run, the 'Abbāsids did not succeed by coercion but by negotiating with local communities and by supporting new legal trends. The promotion of Hanafismand, to a lesser extent, Mālikism - as well as job opportunities offered to those who had reached a high position in the Hanafī school, encouraged scholars to adhere to this school. They hoped that it would allow them to find a position as a judge, scribe, or professional witness.

On the whole, the transition from the 'ancient' to the 'personal' (or 'doctrinal') schools of law can be seen as the tension between two forms of identity. At the local level, the Muslim people of the main cities defended their material and moral interests with their attachment to local customs, rooted in the traditions of the Companions and Successors. At the centre, the 'Abbāsid state engaged in a programme of centralization and standardization that can be seen as an attempt to enhance an Islamic 'universalism'. At the same time, the development of Prophetic hadith - which eventually replaced, to a large extent, the older traditions of the Companions and of the Successors-appears as the most important factor in the development of a universal Islamic model, that of the Prophet Muhammad. Relationships between religious scholars and the state have often been seen as antagonistic, each side trying to assert its authority over the other. From 
another point of view - that of a struggle between local practices and Islamic universalism - both the state and the scholars were moving toward the same end. In two distinct ways, they promoted a comprehensive identity over and above local traditions. The support of doctrinal schools of law contributed greatly to the reshaping of urban selfdefinitions. Muslims identified more and more with this new universal concept of knowledge, and less and less with local trends of thought.

I am grateful to Christopher Melchert for his comments on a previous draft of this paper. I thank Caroline Treadwell and Adam Talib for their careful reading and corrections. This article was written with the support of the Marie Curie Actions of the European Commission.

\section{Notes}

${ }^{1}$ G. Makdisi, 'Tabaqāt-Biography: Law and Orthodoxy in Classical Islam', Islamic Studies 32 (1993), 379, 390-1; C. Melchert, 'The Formation of the Sunnī Schools of Law', in W. B. Hallaq (ed.), The Formation of Islamic Law (Aldershot, 2004), 354-5.

2 N. Tsafrir, The History of an Islamic School of Law. The Early Spread of Hanafism (Cambridge MA, 2004).

3 J. Schacht, Introduction au droit musulman (Paris, 1983), 55. Cf. Makdisi, 'Tabaqāt-Biography', 390-1; Melchert, The Formation of the Sunni Schools of Law, 9th10th Centuries C.E. (Leiden, 1997), 35.

${ }^{4}$ N. Hurvitz, 'Schools of Law and Historical Context: Re-examining the Formation of the Hanbalī Madhhab', Islamic Law and Society 7 (2000), 42-6; W. B. Hallaq, 'From Regional to Personal Schools of Law? A Reevaluation', Islamic Law and Society 8 (2001); see also S. Judd, 'Al-Awzā' 1 and Sufyān al-Thawrī: The Umayyad Madhhab?', in P. Bearman, R. Peters, and F. E. Vogel (ed.), The Islamic School of Law. Evolution, Devolution, and Progress (Cambridge, 2005), 11, 22.

${ }^{5}$ On the definition of 'identity', conceived in terms of boundaries between cultural models, see Philip Wood's introduction to the present volume.

${ }^{6}$ Ibn al-Muqaffa', Risāla fī al-șaḥāba, in C. Pellat, Ibn al-Muqaffa' (mort vers 140/757) 'conseilleur' $d u$ calife (Paris, 1976). On this epistle, see, amongst other references, J. Schacht, The Origins of Muhammadan Jurisprudence (Oxford, 1950), 1023; S. D. Goitein, 'A Turning Point in the History of the Muslim State (Apropos of the Kitāb al-șahāāba of Ibn al-Muqaffa')', in Studies in Islamic History and Institutions (Leiden, 1968); A. K. S. Lambton, State and Government in Medieval Islam. An Introduction to the Study of Islamic Political Theory: The Jurists (New York, 1981), 51; J. E. Lowry, 'The First Islamic Legal Theory: Ibn al-Muqaffa' on Interpretation, Authority, and the Structure of the Law', Journal of the American Oriental Society 128 (2008), 25-40.

${ }^{7}$ Ibn al-Muqaffa ', Risāla fì al-ṣaḥāba, 40-2.

${ }^{8}$ Schacht, Origins, 21-35. 
${ }^{9}$ On the Meccan legal trend, see H. Motzki, The Origins of Islamic Jurisprudence: Meccan Fiqh before the Classical Schools (Leiden, 2002).

${ }^{10}$ See M. Sharon, Black Banners from the East. Vol. 1, The Establishment of the 'Abbāsid State: Incubation of a Revolt (Leiden, 1983), 147; M. Sharon, Black Banners from the East. Vol. 2, Revolt. The Social and Military Aspects of The 'Abbāsid Revolution (Jerusalem, 1990), 250f.; P. Crone, 'On the Meaning of the 'Abbasid Call to al-Rid̄a', in C. E. Bosworth et al. (eds.), The Islamic World From Classical to Modern Times (Princeton, 1989), esp. 100-1.

11 Ibn al-Muqaffa', Risāla fì al-șaḥāba, 42-3. See also Lambton, State and Government, 53; P. Crone and M. Hinds, God's Caliph. Religious Authority in the First Centuries of Islam (Cambridge, 1986), 86; Lowry, 'The First Islamic Legal Theory', 36.

${ }^{12}$ Y. Dutton, The Origins of Islamic Law. The Qur'an, the Muwatta' and Madinan 'Amal (London, 1999), 29. On Mālik, see J. Schacht, 'Mālik b. Anas', EI2.

13 B. Jokisch, Islamic Imperial Law. Harun-Al-Rashid's Codification Project (Berlin, 2007), esp. 261-309.

${ }^{14}$ M. Tillier, 'Un espace judiciaire entre public et privé: Audiences de cadis à l'époque 'abbāside', Annales Islamologiques 38 (2004), 497f.

15 S. Bouderbala, Ǧund Miṣr: Étude de l'administration militaire d'Égypte des débuts de l'Islam, 21/642-218/833 (PhD diss., Université Paris 1 Panthéon-Sorbonne, 2008), 267.

${ }^{16} \mathrm{Wak}^{\circ}{ }^{\prime}$, Akhbār al-qud̄āt, 2:58, 70.

17 E. Tyan, Histoire de l'organisation judiciaire en pays d'Islam (Leiden, 1960), $363,369,375 f$.

${ }^{18}$ Schacht, Origins, 100; W. B. Hallaq, The Origins and Evolution of Islamic Law (Cambridge, 2005), 44f.

${ }^{19}$ See al-Jāhiz, Kitāb al-hayawān, 1:87; on the development of early Mālikī texts, see J. E. Brockopp, Early Mālikī Law. Ibn 'Abd al-Hakam and his Major Compendium of Jurisprudence (Leiden, 2000), 66, 73, 89, 111.

${ }^{20}$ In the early third/ninth century, the $q \bar{a} d \underline{\imath} \bar{\imath}$ Ibrāhīm ibn al-Jarrāh usually chose for each case among the legal views of Abū Hanīfa, Abū Yūsuf, Mālik ibn Anas, and Ibn Abī Laylā. Al-Kindī, Akhbār quḍāt Mișr, 432.

${ }^{21}$ M. Tillier, Les cadis d'Iraq et l'État abbasside (132/750-334/945) (Damascus, 2009), 240f., $578 f$.

22 J. Schacht, 'Ibn Abī Laylā', EI2; Tillier, Les cadis d'Iraq, 99.

${ }^{23}$ See, e.g., Wakī', Akhbār al-quḍāt, 3:133-4.

${ }^{24}$ M. Tillier, 'Un traité politique du II'/VIII' siècle: L'épître de 'Ubayd Allāh b. alHasan al- 'Anbarī au calife al-Mahdī', Annales Islamologiques 40 (2006), 142-4.

${ }^{25}$ Tillier, Les cadis d'Iraq, 187-94.

${ }^{26}$ H. Djaït, al-Kûfa. Naissance de la ville islamique (Paris, 1986), $287 \mathrm{f}$.

${ }^{27}$ Schacht, Introduction, 32. 
28 J. Lassner, The Shaping of 'Abbâsid Rule (Princeton, 1980), 58. For the governors of Fustat, see H. Kennedy, 'Central Government and Provincial Elites in the Early 'Abbāsid Califate', Bulletin of the School of Oriental and African Studies 44 (1981), 26-38.

${ }^{29}$ Tsafrir, The History, 30; Tillier, Les cadis d'Iraq, 146-7.

${ }^{30}$ Kennedy, 'Central Government and Provincial Elites', 37; M. Tillier, in al-Kindī, Histoire des cadis égyptiens (Cairo: 2012), 34. On the qạḍ̄s of al-Mawșil under the early 'Abbāsid caliphate, see Kennedy, 'Central Government', 30.

${ }^{31}$ Tillier, Les cadis d'Iraq, 101-1.

${ }^{32}$ Wakī‘, Akhbār al-quḍāt, 2:57.

${ }^{33}$ B. Johansen, 'Wahrheit und Geltungsanspruch: Zur Begründung und Begrenzung der Autorität des Qadi-Urteils im islamischen Recht', in O. Capitani et al., La Giustizia nell' alto medioevo (secoli IX-XI) (Spoleto, 1997), 994; Tillier, Les cadis d'Iraq, 104.

${ }^{34}$ Crone and Hinds, God's Caliph, 80-2.

${ }^{35}$ Tsafrir, The History, 40f.

${ }^{36}$ Tsafrir, The History, 40; Tillier, Les cadis d'Iraq, 148f.

${ }^{37}$ Hallaq, The Origins and Evolution, 106-7. Cf. Schacht, Origins, 231.

${ }^{38}$ The reason of this bad reputation is unclear. One would expect that Iraqi scholars had a bad reputation in Syria because of their opposition to the Umayyads. Ibn alMuqaffa' 's text suggests, however, that these scholars had suffered from a bad reputation in Iraq itself because of their collaboration with unjust rulers. In his Risāla, Ibn alMuqaffa' encourages the caliph to rely more on Iraqi people. Ibn al-Muqaffa', Risāla fi al-șahāba, 39.

${ }^{39}$ See Tsafrir, The History, 24-6; M. Q. Zaman, Religion and Politics under the Early 'Abbāsids: The Emergence of the Proto-Sunnī Elite (Leiden, 1997), 78-9.

${ }^{40}$ See Judd, 'al-Awzā'̄ì and Sufyān al-Thawrī', 22.

${ }^{41}$ Schacht, Origins, 61; Dutton, The Origins of Islamic Law, 31f.

${ }^{42}$ Tsafrir, The History, 40-1; Tillier, Les cadis d'Iraq, $151 \mathrm{f}$.

43 Tsafrir, The History, 25-7.

${ }^{44}$ See W. Madelung, 'The Early Murji'a in Khurāsān and Transoxania and the Spread of Hanafism', Der Islam 59 (1982), 32-9.

${ }^{45} \mathrm{He}$ was suspected of supporting the Shī'̄i rebel Muhammad ibn 'Abd Allāh alNafs al-Zakiyya in 145/762, and he was supposedly imprisoned after he refused to be appointed as a qād̄ì by al-Manșūr. See Zaman, Religion and Politics, 73; J. Schacht, 'Abū Hanīfa al-Nu 'mān', EI2.

${ }^{46}$ Tsafrir, The History, passim.

47 Sawwār ibn 'Abd Allāh (d. 156/773), qāọ̄ of Basra from 140/757-8 until his death. See Wakī', Akhbār al-quḍ̄at, 2:57f.; Ibn Qutayba, Kitāb al-ma'ārif, 590; alBalādhurī, Ansāb al-ashrāf, 3:257.

${ }^{48}$ On this scholar, see supra, footnote 24. 
${ }^{49}$ See, e.g., Jokisch, Islamic Imperial Law, 251, 264, 274, 280.

${ }^{50}$ Tsafrir, The History, 36.

${ }^{51}$ Tsafrir, The History, 40; Tillier, Les cadis d'Iraq, 148.

${ }^{52}$ See P. M. Cobb, White Banners. Contention in 'Abbasid Syria, 750-880 (Albany, 2001), 43f.

${ }^{53}$ See H. Kennedy, The Early Abbasid Caliphate. A Political History (London and Sydney, 1981), 67-70; L. Veccia Vaglieri, 'Ibrāhīm b. 'Abd Allāh', EI2.

${ }^{54}$ Tillier, Les cadis d'Iraq, 167.

${ }^{55}$ Wakī‘, Akhbār al-quḍāt, 2:128.

${ }^{56}$ For consultations of local elites in Egypt, see al-Kindī, Akhbār quḍat Miṣr, 369, 370.

${ }^{57}$ Tyan, Histoire de l'organisation judiciaire, 171.

${ }^{58}$ Wakī‘, Akhbār al-quḍāt, 3:241. See also Ibn al-Athīr, al-Kāmil fì al-ta'rīkh (Beirut, 1982), 5:274.

59 Wakī‘, Akhbār al-quḍ̄̄t, 3:243; al-Khațīb, Ta'rīkh Madīnat al-Salām (Beirut, 2001), 16:156.

${ }^{60}$ On this scholar, see Ibn Sa'd, al-Ṭabaqāt al-kubrā (Beirut, 1968), 5:420; alMizzī, Tahdhīb al-kamāl (Beirut, 1980), 11:372-5; al-Dhahab̄̄, Siyar a 'ām al-nubalā' (Beirut, 1981-1988), 7:425-7.

${ }^{61}$ Wakī‘, Akhbār al-qud̄àt, 3:242; al-Khațīb, Ta'rīkh Madīnat al-Salām, 16:158. See also al-Nubāhī, Ta'rīkh quḍ̄at al-Andalus (Beirut, 1983), 10. On Rabī'a al-Ra'y, see al-Ziriklī, al-A ' lām (Beirut, 1997), 3:17; Ibn Khallikān, Wafayāt al-a yānn (Beirut, 1994), $2: 288$

${ }^{62}$ Al-Kindī, Akhbār quḍāt Miṣr, 376.

${ }^{63}$ Ibn 'Asākir, Ta'rīkh Madīnat Dimashq (Beirut, 1995), 48:101.

${ }^{64}$ See M. Tillier, 'Les 'premiers' cadis de Fusțāt et les dynamiques régionales de l'innovation judiciaire (750-833),' Annales Islamologiques 45 (2011), 218-20.

${ }^{65}$ On this proto-Hanafī scholar, who became qā $\bar{l} \bar{l}$ in Basra in 191-2/806-7 and from 198/813 until 202/817-8, see Wakī', Akhbār al-quḍāt, 2:151, 157; al-Șaymarī, Akhbār Abī Hanīfa (Beirut, 1985), 164; al-Khațīb, Ta'rīkh Madīnat al-Salām, 3:405-10; Ibn Abī l-Wafā', al-Jawāhir al-muḍiyya, ed. 'Abd al-Fattāḥ Muḥammad al-Ḥulw (Cairo, 1993), 3:99-203.

${ }^{66} \mathrm{Wakī}^{\prime}$, Akhbār al-quḍāt, 2:131. Cf. Ibn Hajar, Tahdhīb al-tahdhīb (Beirut, 1984), $7: 424$

${ }^{67}$ See Tsafrir, The History, 34; see also Melchert, 'The Formation of the Sunn̄̄ Schools', 363.

${ }^{68}$ R. Peters, 'Wakf', EI2.

${ }^{69}$ Al-Khașșāf, Aḥkām al-awqāf (Beirut, 1999), 94.

70 Tsafrir, The History, 34. On Abū Hanīfa's opposition to waqfs, see also P. Hennigan, The Birth of a Legal Institution: The Formation of the Waqf in Third-Century A.H. Hanafì Legal Discourse (Leiden, 2004), xix. 
71 Al-Kindī, Akhbār quḍ̄t Miṣr, 372-3. Cf. Ibn al-Mulaqqin, Nuzhat al-nużzār, 116-7; al-Qalqashandī, Șubḥ al-a shā (Cairo: 1913-22), 1:418. On this qāậ̀, see Tyan, Histoire de l'organisation judiciaire, 156.

${ }^{72}$ Al-Kindī, Akhbār quḍāt Mișr, 371-2.

73 On the Hanafī position, see al-Ṭahāwī, Ikhtilāf al-fuqahā' (Islamabad, 1971), 169; al-Sarakhsī, al-Mabsūṭ (Beirut, 1406/1986), 9:102. On the Mālikī position, see Saḥnūn, al-Mudawwana l-kubrā (Beirut, n.d.), 6:214; Ibn Farḥūn, Tabṣirat al-ḥukkām (Beirut, 1995), 2:201-2.

${ }^{74}$ Al-Ṭahāwī, Ikhtilāf al-fuqahā', 158.

75 Tsafrir, The History, 36; Tillier, Les cadis d'Iraq, 179.

76 Tsafrir, The History, 24; Tillier, Les cadis d'Iraq, 176-7.

${ }^{77}$ Tillier, Les cadis d'Iraq, 180.

${ }^{78}$ Wakī', Akhbār al-qud̄àt, 2:140. See Tillier, Les cadis d'Iraq, 178.

${ }^{79}$ Wakī', Akhbār al-quḍāt, 2:142.

${ }^{80}$ Kennedy, 'Central Government', 34-5.

${ }^{81}$ See supra.

${ }^{82}$ Tsafrir, The History, 96.

${ }^{83}$ Tsafrir, The History, 27.

${ }^{84}$ See the list of the Egyptian $q \bar{a} \hat{d} \bar{\imath} \mathrm{s}$ in M. Tillier, 'Introduction', in al-Kindī, Histoire des cadis égyptiens, 28-30.

${ }^{85}$ Al-Kindī, Akhbār quḍāt Miṣr, 392. On Abū al-Bakhtarī, see Tillier, Les cadis d'Iraq, 154 and index.

${ }^{86} \mathrm{G}$. Wiet, L'Égypte arabe de la conquête arabe à la conquête ottomane (Paris, 1937), 71 .

${ }^{87}$ Kennedy, 'Egypt as a Province of the Islamic Caliphate', in C. F. Petry, The Cambridge History of Egypt (Cambridge, 1998), 82.

${ }^{88}$ Al-Kindī, Akhbār quạāt Mișr, 449.

89 Al-Kindī, Akhbār quḍāt Miṣr, 447, 451f. On this qāộ̄, see also M. Hinds, 'Mihnna', EI2. The mihnna is the 'inquisition' that al-Ma'mūn organized to impose the dogma of the creation of the Qur'an.

${ }^{90}$ See Tillier, in al-Kindī, Histoire des cadis égyptiens, 37.

${ }^{91}$ Tsafrir, The History, 27, 35.

92 Tsafrir, The History, 37; Tillier, Les cadis d'Iraq, 171-2.

93 Tillier, Les cadis d'Iraq, 697.

${ }^{94}$ On the persistence of regional trends within the classical madhhabs, see W. B. Hallaq, 'From Regional to Personal Schools', 18.

${ }^{95}$ Jokisch, Islamic Imperial Law, $287 f$. 